https://dx.doi.org/10.4314/ijs.v22i3.12

Ife Journal of Science vol. 22, no. 3 (2020)

\title{
HAEMATOLOGY AND SERUM BIOCHEMISTRY OF BROILER CHICKENS OFFERED EXTRACTS OF DRIED ROSELLE PLANT (Hibiscus sabdariffa) CALYX IN DRINKING WATER
}

\author{
${ }^{1}$ Asaniyan, E. K.* and ${ }^{2}$ Akinduro, V. O. \\ ${ }^{1}$ Department of Animal Production and Health, Olusegun Agagu University of Science and Technology, P.M.B.353, \\ Okitipupa. Ondo State, Nigeria. \\ ${ }^{2}$ Department of Animal Science, College of Agriculture, Osun State University, P. M. B 4494, Osogbo, Osun State, \\ Nigeria. \\ *Corresponding author's e-mail: ekasaniyan@gmail.com; Tel.: +2348035726703 \\ (Received: $17^{\text {th }}$ June, 2020; Accepted: $12^{\text {th }}$ September, 2020)
}

\section{ABSTRAC'T}

\begin{abstract}
The challenge of antibiotics resistance and the fatality of its residues in human and animal health led to the ban of antibiotic growth promoters in animal diets. This has prompted the search for alternatives; especially through phytobiotic investigations. Therefore, this study investigated the effects of aqueous dried calyx extract of roselle plant on the haematological and serum biochemical responses of broiler chickens with the aim of establishing its optimal level as nutrient additive. The five varying concentration levels- 0, 5, 10, 20 and $30 \mathrm{ml}$ of 2 litres of calyx extract solution per litre of drinking water were treatments T1, T2, T3, T4 and T5 respectively. Thirty broiler chickens were randomly assigned per treatment of three replicates each. The experiment lasted for eight weeks.

The results revealed significant differences in the haematological parameters. However, the values of white blood cells (WBC) $\left(11400.00 \times 10^{3} / \mu \mathrm{l}-13466.67 \times 10^{3} / \mu \mathrm{l}\right)$, lymphocyte (ranged between 48.33 and $61.33 \%$ ), monocytes (2.00-3.67\%), eosinophils (1.67-5.00\%) and basophil $(0.00-1.00 \%)$ were within the normal range for healthy chickens. Hence, roselle plant aqueous extract maintained the haematological content of the blood. The level of lymphocyte revealed adequate production of antibodies that prevented the occurrence of bacterial infection or allergic condition throughout experimental period. The influence of aqueous roselle plant on the levels of aspartate transaminase (AST) and albumin (ALB) indicated uncompromised liver function. Therefore, haematological and serum biochemistry parameters showed enhanced health and the wellbeing of the broiler chickens. The $5 \mathrm{ml}$ and $10 \mathrm{ml}$ levels of the extract of dried roselle calyx in drinking water were found to be similarly optimal in terms of lymphocyte levels. Levels above $10 \mathrm{ml}$ could be detrimental to the health and wellbeing of the chickens.
\end{abstract}

Key words: Blood constituents, Chicken health, Drinking water, Roselle calyx extract

\section{INTRODUCTION}

The health and welfare of broiler chicken are of concern in achieving good performance and returns on production. Efforts are constantly ongoing in maintaining their healthy performance without compromising the safety of broiler meat. Nutritional investigations into reduction in production cost through alternative ingredients never compromised the fact that good health is an indicator of excellent performance. The necessity of controlling infectious pathogens and increasing feed efficiencies led to the discovery of antibiotics (Engberg et al., 2000).

Antibiotics are routinely used to treat and prevent infections in humans and animals. However, scientific evidence suggests that the massive use of these compounds led to increased problem of antibiotic resistance (Furtula et al., 2010; Forgetta et al., 2012), and presence of antibiotics residues in feed and environment (Carvalho and Santos, 2016; Gonzalez and Angeles, 2017), compromised human and animal health (Diarra et al., 2010). This consequently led to the ban of antibiotic growth promoters in animal diets in the European Union in 2006. Therefore, there are consistent efforts to find the effective alternatives to prevention and control of spread of resistant bacteria through plant phytobiotic investigations (Diarra and Malouin, 2014).

Black cumin seed (Khalaji et al., 2011; Abd ElHack et al., 2018), pawpaw seed (Bolu et al., 2009); bitter leaf (Nwaoguikpe, 2010), have all been reported to have a growth promoting effect on different poultry such as chicken and quail which serve varying purposes such as meat and egg production. Furthermore, the beneficial use of 
plant seeds and plant extracts in ruminants is well documented (Faniyi et al., 2016; Hernandez et al., 2017). Consequently, plant parts or their extracts are of benefits to livestock performance. Feeding the broiler chickens with the diets containing antibiotic alternatives alleviated the negative effects of removing antibiotics from their diets (Yakhkeshi et al., 2011). Licorice (Glycyrrbiza glabra) extract in drinking water can reduce abdominal fat and serum levels of low density lipoprotein cholesterol and total cholesterol without any adverse effects on broilers performance and immune status (Khamisabadi et al., 2015).

Roselle is a tropical shrub belonging to the family Malvacea which produces red, dark red and green form of calyces. The chemical composition of the red calyces revealed that they are good sources of vitamin $\mathrm{C}$, flavonoids, minerals and antioxidants (Babalola et al., 2001; Wong et al., 2002). Roselle aqueous extract is usually processed into a sour tasting refreshing drink called Zobo in Nigeria (Fasoyiro et al., 2005). The acid content of the calyces increases during growth but decreases when it reaches maturity or ripens (Frimpong, et al., 2014). The roselle plant is considered an antiseptic, emollient, sedative and tonic agent that produces soothing and invigorating effects in the body (Olaleye, 2007). In human, it aids digestion, promotes kidney function, improves cardiovascular health and helps reduce fever (Fasoyiro et al., 2005). Consequently, the roselle calyx has the potential of being used to supplement or replace synthetic antibiotics in drinking water of broiler chickens as farmers are unrelentingly sourcing for alternative ways to improve their performance.

Blood provides the opportunity to assess the physiological, pathological and nutritional status of animals through the evaluation of its constituents and the presence of metabolites (Nseabasi et al., 2014). The haematological parameters which affect health, production and adaptability to environmental conditions in livestock include the packed cell volume (PCV), haemoglobin $(\mathrm{Hb})$, total protein $(\mathrm{TP})$ and serum globulin (SG) (Medugu et al ., 2010; Adenkola et al., 2011). Benerjee, (2008) reported normal blood values for domestic fowl to be a PCV 25-45\%, RBC 2-4 x 10 $0^{6}$ Hb 7-13g/dl, WBC 9-31 x 10 $0^{3}$, and total serum protein 5-7\%. Haematological components are valuable in monitoring feed toxicity especially feed constituents that affects the formation of blood (Amusa et al., 2015). Consequently, effects of aqueous dried calyx extract of roselle plant administered through drinking water on the serum biochemistry and haematological parameters of broiler chickens were investigated. Hence, this study aimed at establishing the optimal level of aqueous dried calyx extract of roselle plant as nutrient additive in broiler chicken production.

\section{MATERIALS AND METHOD}

The study was conducted at the Poultry Unit of the Teaching and Research Farm of College of Agriculture, Ejigbo Campus, Osun State University, Osun State, Nigeria. The farm is located on latitude $7^{\circ} 54^{1} \mathrm{~N}$ and longitude $4^{\circ} 18^{1} \mathrm{E}$ and $4^{\circ} 54^{1} \mathrm{E}$ at an altitude of $426 \mathrm{~m}$ above the sea level.

\section{Housing}

The chicks were raised in a standard deep litter system for 8 weeks (56 days). The poultry house and the necessary equipment used were fumigated and disinfected using formalin, potassium permanganate and Dettol.

Dried Calyx Extract The dried calyx from Roselle plant purchased from a local market was measured using a sensitive scale. Two hundred grams (200 g) of the sample was boiled in 2 litres of water for 10 minutes to obtain the extract solution of the flower extract. After boiling, the extract solution obtained was applied into the drinking water with the aid of measuring cylinder.

\section{Management and Experimental Procedure}

One hundred and fifty (150) Abor acre day- old broiler chicks were procured from a reputable hatchery in Ibadan, Oyo State. The chicks were randomly assigned to five (5) treatments (30 birds per treatment) replicated three (3) times with ten (10) birds per replicate under a completely randomized design (CRD) experiment. They were brooded on deep litter system using 200 watts electricity bulbs and coal pots for fourteen days. The necessary vaccination program: Newcastle Disease Vaccine (NDV intraocular), Gumboro (Infectious Bursa Disease) and Newcastle Disease 
Vaccine (NDV Lasota) were carried out at appropriate times. Anti-stress (solution of glucose and vitamins) was also administered to the birds on arrival. The birds were generally fed starter diet (Table 1) for four weeks without the experimental drinking water. At the finisher phase, the birds were given aqueous extracts of calyx at various levels of inclusion in drinking water at finisher phase and fed finisher diet (Table1) for 4 weeks. Both routine (cleaning of pen, changing of water, and washing of feeders and drinkers) and occasional (medication and vaccination) management practices were thoroughly carried out with strict hygiene measures. Each of the five treatments represented the concentration of the dried calyx extract from roselle plant per litre of drinking water. The concentrations were $0,5,10$, 20 and $30 \mathrm{ml}$ of extract solution per litre of drinking water for treatments T1, T2, T3, T4 and T5 respectively.

Table 1: Gross Composition of Broiler Diets

\begin{tabular}{lll}
\hline Ingredients & \multicolumn{2}{c}{ Composition } \\
\hline Starter (23\% Crude protein) & $\begin{array}{l}\text { Finisher (20\% Crude } \\
\text { protein) }\end{array}$ \\
\hline Maize & 50.00 & 50.00 \\
Wheat offal & 3.90 & 10.50 \\
Brewer dried grain & 5.00 & 10.00 \\
Groundnut cake & 10.00 & 12.00 \\
Soya bean meal & 24.50 & 13.00 \\
Fish meal & 3.00 & - \\
Oyster shell & 0.20 & 0.20 \\
Bone meal & 2.50 & 3.00 \\
Methionine & 0.25 & 0.30 \\
Lysine & - & 0.30 \\
Premix & 0.25 & 0.30 \\
Salt & 0.40 & 0.40 \\
\hline Total & $\mathbf{1 0 0}$ & $\mathbf{1 0 0}$ \\
\hline Fibre level & $4.34 \%$ & $4.87 \%$ \\
\hline Energy & $2822.99 \mathrm{MEkcal} / \mathrm{kg}$ & $2717.38 \mathrm{MEkcal} / \mathrm{kg}$ \\
\hline
\end{tabular}

Serum and Haematological and Biochemical Analysis

At the end of the experimental period (8 weeks), feed was withdrawn 12 hours prior to blood collection. Three birds were selected randomly from each replicate; the birds were bled using a sterilized disposable syringe and needle from punctured vein to aspirate $10 \mathrm{ml}$ of blood samples from each bird. Five (5) $\mathrm{ml}$ of blood samples were collected into bottles treated with ethylene diamine tetra acetic acid (EDTA) for haematological assay. The remainder of each blood sample was allowed to coagulate to produce serum for blood chemistry measurements (Ochei and Kolhatkar, 2008).

The samples were preserved deep-frozen $\left(-20^{\circ} \mathrm{C}\right)$ before being transported to the laboratory for analysis. The haematological parameters determined were red blood cell (RBC), packed cell volume (PCV), haemoglobin ( $\mathrm{Hb})$, mean corpuscular volume (MCV), mean corpuscular haemoglobin ( $\mathrm{MCH})$ mean corpuscular haemoglobin concentration (MCHC), lymphocytes, basophils, neutrophils, monocytes and eosinophil. The haematological parameters were determined by the use of Neubauer haematocytometer (Lamb, 1991). The mean corpuscular volume (MCV), mean corpuscular haemoglobin $(\mathrm{MCH})$, mean corpuscular haemoglobin concentration (MCHC) were computed using the formulae outlined by Jain (1986). Samples for biochemical parameters were first centrifuged and decanted. Sigma kits were thereafter used to determine protein, globulins and albumins. Serum aspartic aminotransferase (AST), alkaline phosphatase (ALP) and alkaline 
aminotransferase (ALT) were determined using the procedure of Baker and Silverton (1985).

\section{Statistical Analysis}

Data obtained were subjected to one-way analysis of variance (ANOVA) using the Statistical Analysis Package (SAS (2008) version 9.1, USA). Where significant differences were found, the means were compared using the Duncan's multiple range test of the same statistical package.

\section{RESULTS AND DISCUSSION}

The result of haematological and serum parameters are as presented in tables 2 and 3, respectively. There were significant $(\mathrm{P}<0.05)$ differences in five out of the ten haematological parameters considered: white blood cell counts (WBC), lymphocytes, monocytes, eosinophil and basophil. There were no significant $(\mathrm{P}>0.05)$ differences in packed cell volume (PCV), haemoglobin counts (HBC), red blood cell counts (RBC), blood platelets and heterophils values. This suggests unequal influence of the treatments (varying levels of aqueous extract of dried roselle calyx in drinking water) on the haematological parameters of the broiler chickens (Al-Baghdadi, 2011). However, all the haematological values were within the normal range for healthy chickens (Mirtuka and Rawnsley, 1997; CCAC, 1993).

Therefore, non-significant influence of the treatments on the few of the haematological parameters signified their uncompromised physiological relevance in the broiler chickens. The broiler chickens on T2 (5 ml extract level) had the highest WBC value $\left(13466.67 \times 10^{3} / \mu \mathrm{l}\right)$ and T5 $\left(11400.00 \times 10^{3} / \mu \mathrm{l}\right)(30 \mathrm{ml}$ extract level $)$ were significantly $(\mathrm{P}<0.05)$ different from one another; but both were similar $(\mathrm{P}>0.05)$ to those birds on $\mathrm{T} 1\left(12806.67 \times 10^{3} / \mu \mathrm{l}\right)(0 \%$ without extract , T3 $\left(13023.33 \times 10^{3} / \mu \mathrm{l}\right)(10 \mathrm{ml}$ extract level $)$ and $\mathrm{T} 4$ $\left(13000.00 \times 10^{3} / \mu \mathrm{l}\right)(20 \mathrm{ml}$ extract level $)$ which were statistically insignificant. The white blood cells (WBC) protect the body against infection and disease with the production of antibodies through the process of phagocytosis (Soetan et al., 2013). Therefore, the higher values of WBC in T2, T3 and $\mathrm{T} 4$ above treatment $\mathrm{T} 1$ indicated that the roselle calyx extract has the potential of enhancing better immune system development in broiler chickens. However, such potential reflected most at $5 \mathrm{ml}$ extract level (T2) even though similar potential could still be realised at treatments $\mathrm{T} 3$ and T4.

This corroborated the report of Olaleye (2007) that roselle calyx extract is considered an antiseptic, emollient, sedative and tonic agent that produces soothing and invigorating effects in the body. All the investigated WBC differentials showed significant $(\mathrm{P}<0.05)$ differences across the treatments except heterophils. Generally, WBC differentials are involved in recognising body intruders, killing harmful bacteria and creating antibodies to protect the body against future exposure to some pathogens like bacteria and viruses. The lymphocytes value for the broiler chickens across the treatments ranged between 48.33 and $61.33 \%$. This is in agreement with values of $45-75 \%$ and $58.10-71.70 \%$ reported by Gylstorff (1983) and Nemi (1993) respectively.

Lymphocyte were significantly $(p<0.05)$ different in values; with decreasing magnitudes as the extract levels increases. Broiler chickens under treatment T5 (48.33\%) (30 ml extract level) had the least value of lymphocytes similar to treatment T4 $(58.33 \%)$ but significantly $(\mathrm{p}<0.05)$ different from other treatments. However, treatments T2 $(61.00 \%)$ and $\mathrm{T} 3(60.67 \%)$ had similar values to $\mathrm{T} 1$ $(61.33 \%)$ (control $(0 \mathrm{ml})$ without extract $)$ of the highest lymphocyte value. The decreasing values of lymphocytes as the extract level increases could be a signal that the extract level might not necessarily be high before realising its physiological relevance to lymphocyte production and effectiveness in broiler chickens. Also, similar lymphocyte values observed in extract-containing treatments with treatment $\mathrm{T} 1 \quad(0 \mathrm{ml}$ without extract) could be as a result of absence of disease condition that could trigger pronounced physiological response of lymphocytes. This was evident in the healthy condition of the experimental birds throughout the duration of the study.

There were significant $(\mathrm{P}<0.05)$ differences in the values of monocytes (2.00-3.67\%). This value range is lower than the $16 \%$ and $8.10-16.10 \%$ reported for broiler chickens by Sebastian et al., (2012) and Gylstorff, (1983) respectively; but treatments T2 $(2.33 \%), \mathrm{T} 3(2.00 \%)$ and $\mathrm{T} 4$ 
$(2.67 \%)$ had their values within normal range 0 $3 \%(\mathrm{Kahn}, 2005)$ while treatments $\mathrm{T} 1(3.33 \%)$ and T5 $(3.67 \%)$ had their values slightly outside the normal range. Birds on T5 had the highest value of monocytes and was significantly $(p<0.05)$ different from others except T1. Those on T2, T3 and T4 had similar values but T4 was not significantly $(\mathrm{P}>0.05)$ different from $\mathrm{T} 1$.

Monocytes are the largest member of the white blood cells differentials with migrating capacity to various tissues of the body to eliminate harmful and dead matters. Consequently, the white blood cells values that were virtually high in all the treatments containing the extracts from roselle calyx was not as a result of inflammation or disease which ordinarily should have increased the monocyte count but the antioxidant property of the extract was responsible for maintaining white blood cell counts (Wang et al., 2000; Essa et al., 2006). Eosinophil values were significantly $(\mathrm{P}<0.05)$ different from one another across the treatments. T4 $(5.00 \%)$ was significantly $(\mathrm{P}<0.05)$ different from T1 $(1.67 \%)$. Those on T4 were similar to those on T2 (4.00\%), T3 (3.67\%) and T5 $(3.33 \%)$ while those birds on $\mathrm{T} 1 \mathrm{had}$ similar values with $\mathrm{T} 3$ and $\mathrm{T} 5$. The range of value obtained for eosinophil $(1.67-5.00 \%)$ was similar to the range of $1.20-3.10 \%$ reported by Nemi (1993) for broiler chickens. Basophil values were as well significantly $(\mathrm{P}<0.05)$ different across the treatments. Though, treatment T4 $(1.00 \%)$ significantly $(\mathrm{P}<0.05)$ different from T3 $(0.00 \%)$; but had similar values of basophil with $\mathrm{T} 1$ $(0.33 \%)$, T2 $(0.33 \%)$ and T5 $(0.33 \%)$ while those on T3 were also similar to T1, T2 and T5.

The basophil value range of $0.00-1.00 \%$ obtained falls outside the normal range of 1.5$2.5 \%$ reported by Nemi (1993). Eosinophils fight against the activities of larger parasites such as worms and modulate allergic inflammatory responses while basophils establish defence against allergic reactions from parasites and bacteria. The various deviations of eosinophils and basophils values could be attributed to the different experimental conditions under which the studies were conducted. However, the eosinophils and basophils were within the range reported by Nanbol et al. (2016). Overall, values of the haematological parameters obtained from this study pointed to the normal health condition of the experimental broiler chickens.

The serum biochemical parameters as presented in table 3 did not show distinct significant $(\mathrm{P}<0.05)$ differences of the serum parameters across the treatments. Aspartate transaminase (AST) and albumin (ALB) were the only parameters that showed significant differences; others (alanine transaminase (ALT), total protein (TP), cholesterol (CHOL), triglyceride and high density lipoprotein (HDL)) were not. Serum biochemical parameters are a reflection of the health, nutrition, climate and management exposure of animals. Hence, serum biochemical parameters can be indicators of the productive performance of the broiler chickens and of metabolic diseases.

The aspartate transaminase (AST) values of broiler chickens under T4 (40.91 U/L) $(20 \mathrm{ml}$ extract level) had the highest value that was significantly $(\mathrm{P}<0.05)$ different from other treatments. Those birds on treatments T1 (26.82 $\mathrm{U} / \mathrm{L})(0 \mathrm{ml}$, without extract), T2 (21.53 U/L) (5 ml extract level) and T5 (22.22 U/L) $(30 \mathrm{ml}$ extract level) had similar AST values while those on T3 (11.77 U/L) (10 ml extract level) with the least value was significantly different from all the treatments. AST and ALT are the indicators of hepatic function. Treatment T4 with the highest level of AST (40.91 U/L) that was significantly different from the other treatments, did not show any liver dysfunction along with others that were virtually similar. This could be as a result of the influence of the antioxidant potential of the extract that impacted beneficially on the physiological functions of birds especially the ALT. However, the combined high levels of AST and ALT could be detrimental to liver function and consequently compromise the broiler chickens' health. The albumin level of broiler chickens in treatment T5 had the highest value $(1.98 \mathrm{~g} / \mathrm{dl})$ which was significantly different from treatment T1 $(0.97 \mathrm{~g} / \mathrm{dl})$ but both were similar to treatments T2 $(1.26 \mathrm{~g} / \mathrm{dl})$, T3 $(1.34 \mathrm{~g} / \mathrm{dl})$ and T4 $(1.59 \mathrm{~g} / \mathrm{dl})$. The albumin values of $0.97-1.98 \mathrm{~g} / \mathrm{dl}$ observed in this study did not fall within the range of $25.00-45.00 \mathrm{~g} / \mathrm{dl}$ and $10.80-16.00 \mathrm{~g} / \mathrm{dl}$ reported by Harr (2002) and Ross et al. (1978) respectively. These deviations could be associated 
with broiler breed and the treatment levels of aqueous extract of roselle calyx. Total serum protein and albumin serve as a measure of biosynthetic production of plasma proteins by the liver. Therefore, the level of albumin supported the functionality of the liver; hence broiler chickens' health was enhanced by the Hibiscus sabdariffa extract (Oladele and Ayo, 1999).

Table 2: Effect of Varying Levels of Aqueous Extracts from Dry Calyx of Roselle Plant (Hibiscus sabdariffa) on Haematological Indices of Broiler Chickens

\begin{tabular}{|l|l|l|l|l|l|l|}
\hline Parameters & $\begin{array}{l}\text { T1 } \\
\mathbf{( 0 ~} \mathbf{~ m l})\end{array}$ & $\begin{array}{l}\text { T2 } \\
\mathbf{( 5 ~} \mathbf{~ m l})\end{array}$ & $\begin{array}{l}\text { T3 } \\
\mathbf{( 1 0} \mathbf{~ m l})\end{array}$ & $\begin{array}{l}\text { T4 } \\
\mathbf{( 2 0} \mathbf{~ m l})\end{array}$ & $\begin{array}{l}\text { T5 } \\
\mathbf{( 3 0} \mathbf{~ m l})\end{array}$ & $\mathbf{\pm S E M}$ \\
\hline PCV $(\%)$ & 30.67 & 23.67 & 25.33 & 29.00 & 24.33 & 3.70 \\
\hline HBC $(\mathrm{g} / \mathrm{dl})$ & 10.17 & 7.45 & 8.20 & 9.47 & 8.00 & 1.16 \\
\hline RBC $\left(\times 10^{6} / \mathrm{mm}^{3}\right)$ & 3.52 & 2.55 & 2.38 & 3.36 & 2.42 & 0.48 \\
\hline Platelet $\left(\times 10^{3} / \mu \mathrm{l}\right)$ & 171666.67 & 183666.67 & 192000.00 & 189000.00 & 116616.67 & 2825.39 \\
\hline WBC $\left(\times 10^{3} / \mu \mathrm{l}\right)$ & $12806.67^{\mathrm{ab}}$ & $13466.67^{\mathrm{a}}$ & $13023.33^{\mathrm{ab}}$ & $13000.00^{\mathrm{ab}}$ & $11400.00^{\mathrm{b}}$ & 600.60 \\
\hline Lymphocytes $(\%)$ & $61.33^{\mathrm{a}}$ & $61.00^{\mathrm{a}}$ & $60.67^{\mathrm{a}}$ & $58.33^{\mathrm{ab}}$ & $48.33^{\mathrm{b}}$ & 3.60 \\
\hline Heterophils $(\%)$ & 33.33 & 32.33 & 34.33 & 32.33 & 40.00 & 2.87 \\
\hline Monocytes $(\%)$ & $3.33^{\mathrm{ab}}$ & $2.33^{\mathrm{c}}$ & $2.00^{\mathrm{c}}$ & $2.67^{\mathrm{bc}}$ & $3.67^{\mathrm{a}}$ & 0.30 \\
\hline Eosinophils $(\%)$ & $1.67^{\mathrm{b}}$ & $4.00^{\mathrm{a}}$ & $3.67^{\mathrm{ab}}$ & $5.00^{\mathrm{a}}$ & $3.33^{\mathrm{ab}}$ & 0.45 \\
\hline Basophil $(\%)$ & $0.33^{\mathrm{ab}}$ & $0.33^{\mathrm{ab}}$ & $0.00^{\mathrm{b}}$ & $1.00^{\mathrm{a}}$ & $0.33^{\mathrm{ab}}$ & 0.26 \\
\hline
\end{tabular}

${ }^{\mathrm{ab}}$ Means in the same row with different superscripts are significantly different $(\mathrm{P}<0.05)$

PCV - Packed cell volume, HBC - Haemoglobin concentration, RBC - Red blood cell, WBC - White blood cell, SEM-Standard Error of Means

Table 3: Effect of varying levels of Aqueous Extracts from Dry Calyx of Roselle (Hibiscus sabdariffa) Plant on Serum Characteristics of Broiler Chickens

\begin{tabular}{|c|c|c|c|c|c|c|}
\hline Parameters & $\begin{array}{l}\text { T1 } \\
(0 \mathrm{ml})\end{array}$ & $\begin{array}{l}\text { T2 } \\
(5 \mathrm{ml})\end{array}$ & $\begin{array}{l}\text { T3 } \\
(10 \mathrm{ml})\end{array}$ & $\begin{array}{l}\text { T4 } \\
(20 \mathrm{ml})\end{array}$ & $\begin{array}{l}\text { T5 } \\
(30 \mathrm{ml})\end{array}$ & \pm SEM \\
\hline Aspartate transaminase (AST) $(\mathrm{U} / \mathrm{L})$ & $26.82^{\mathrm{b}}$ & $21.53^{\mathrm{b}}$ & $11.77^{c}$ & $40.91^{\mathrm{a}}$ & $22.22^{\mathrm{b}}$ & 2.06 \\
\hline Alanine transaminase (ALT) (U/L) & 4.89 & 5.37 & 5.01 & 2.95 & 3.32 & 0.93 \\
\hline Total protein $(\mathrm{g} / \mathrm{dl})$ & 3.18 & 3.63 & 5.55 & 5.15 & 4.39 & 0.82 \\
\hline Albumin (ALB) (g/dl) & $0.97^{\mathrm{b}}$ & $1.26^{\mathrm{ab}}$ & $1.34^{\mathrm{ab}}$ & $1.59^{\mathrm{ab}}$ & $1.98^{\mathrm{a}}$ & 0.27 \\
\hline Cholesterol (mg/dl) & 246.54 & 210.06 & 211.95 & 260.38 & 303.77 & 61.64 \\
\hline Triglyceride (mg/dl) & 65.37 & 66.88 & 84.51 & 91.18 & 78.03 & 9.45 \\
\hline High density lipoprotein $(\mathrm{mg} / \mathrm{dl})$ & 37.50 & 37.08 & 41.25 & 36.49 & 54.10 & 5.92 \\
\hline
\end{tabular}

${ }^{a b}$ Means in the same row with different superscripts are significantly different $(\mathrm{P}<0.05)$

SEM-Standard Error of Means

\section{CONCLUSION}

The haematological and serum biochemistry parameters showed that the aqueous extract of dried roselle calyx supported the health and the wellbeing of the broiler chickens. The $5 \mathrm{ml}$ and the $10 \mathrm{ml}$ levels of the extract of dried roselle calyx in drinking water of broiler chickens were found to be most suitable in terms of lymphocyte levels; however levels above $10 \mathrm{ml}$ could be detrimental to the health and wellbeing of the chickens.

\section{RECOMMENDATION}

Further studies on histopathological profile of birds fed extract of dried roselle calyx is recommended to reveal impact on tissues.. Also, pharmacological potency of the extract can be investigated towards harnessing its accurate administration as supplement for livestock use. 


\section{REFERENCES}

Abd El-Hack, M., Alagawany, M., Arif, M., Emam, M. Saeed, M., Arain, M., Siyal, F., Patra, A., Elnesr, S. and Khan, R. (2018). The uses of microbial phytase as a feed additive in poultry nutrition - A review. Annals of Animal Science, 18: 639-658.

Adenkola, A.Y., Idoga, E.S. and Tughgba, T. (2011).Comparative assessment of erythrocyte osmotic fragility and heamatological parameters of broiler and local chicken during the hot-dry season in Makurdi, Nigeria. Proceedings of 36th Annual Conference of Nigerian Society of Animal production. University of Abuja, Nigeria. Pp 117-119.

Al-Baghdadi, R.J.T. (2011). Physiological effects of roselle calyces extract in some blood parameters in laying hens. AL-Qadisiya Journal of Veterinary Medical Science, 10(1): $54-58$.

Amusa, H.O., Kehinde, R.A. Atoyebi, R.O. and Abu, O.A. (2015). Haematology, serum biochemistry, organ weight changes of Wistar rats fed processed dehulled jack bean (Canavalia ensiformis). Nigerian Journal of AnimalProduction, 42(1): 71-78.

Babalola, S.O., Babalola, A.O. and Aworh, O.C. (2001). Compositional attributes of roselle (Hibiscus sabdariffa). Journal of Food Technology for Africa, 6: 133 - 134.

Baker, F.J. and Silverton, R.F. (1985). Introduction to Medical Laboratory Technology. $6^{\text {th }}$ edition. Butterworth, England. Pp. 120128.

Benerjee, G.C. (2008).Textbook of Animal Husbandry. Bidhan Chandra Krishi Viswadyala. Oxford and IBH publishing company. PVT. LTD.

Bolu, S.A.O., Sola-Ojo, F.E., Olorunsanya, O.A., and Idris, K. (2009). Effect ofgraded levels of dried pawpaw (Carica papaya) deed on the performance, haematology, serum biochemistry and carcass evaluation of chicken broilers. International Journal of Poultry Science, 8: 905-909.

Canadian Council on Animal Care (CCAC), (1993). Breeding, physiological and nutritional parameters by species. Extract from: Guide to the care and use of experimental animals, $2^{\text {nd }}$ Edn., Appendix D (http://www.yonsoi.a.ckr) pp:1-3.

Carvalho, I.T. and Santos, L. (2016). Antibiotics in the aquatic environments: a review of the European scenario. Environment International, 94: 736-757.

Diarra, M.S., Rempel, H., Champagne, J., Masson, L., Pritchard, J. and Topp, E. (2010). Distribution of antimicrobial resistance and virulence genes in Enterococcus spp. And characterization of isolates from broiler chickens. Applied Environmental Microbiology, 76: 8033-8043.

Diarra, M.S. and Malouin, F. (2014). Antibiotics in Canadian poultry productions and anticipated alternatives. Frontiers in Microbiology, 5: 282.

Engberg, R.M., Hedemann, M.S., Leser, T.D. and Jensen, B.B. (2000). Effect of zinc bacitracin and salinomycin on intestinal microflora and performance of broilers. Poultry Science Science, 79:1311-1319.

Essa, M.M., Subrammanian, P., Suthakar, G., Subash, S., Manivasagam, T., Dakshayani, K.B., Sivaperu Mul, R. and Vintothini, G. (2006). Influence of Hibiscus sabdariffa (Gangura) on the levels of circulatory lipid peroxidation products and liver marker enzymes in experimental hyperammonemia. Journal Applied Biomedical, 4: 53-58.

Faniyi, T.O., Prates, E.R., Adewumi, M.K., and Bankole, T. (2016) Assessment of herbs and spices extracts/meal on rumen fermentation: Review. Public aço es e m Medicina Veterinária e Zootecni a.(10), 5: 427- 438 .

Fasoyiro, S.B., Babalola, S.O. and Owosibo, S.B. (2005). Chemical composition and sensory qualities of fruit flavoured roselle (Hibiscus sabdariffa). World Journal of AgriculturalResearch, 1(2): 161-164.

Forgetta, V., Rempel, H., Malouin, F., Vaillancourt, R. Jr., Topp, E. and Dewar, K. (2012 Pathogenic and multidrug-resistant Escherichia fergusonii from broiler chicken Poultry Science, 91: 512-525

Frimpong, G., Joseph, A., Kwabena, O., Samuel, L., Yaw, D. (2014). Potential of aqueous extract of Hibiscus sabdariffa calyces as coloring agent in three pediatric oral 
pharmaceutical formulations. Journal of Applied Pharmacentical Science Vol. 4 (12):001-007.

Furtula, V., Farrell, E.G., Diarrassouba, F., Rempel, H., Pritchard, J. and Diarra, M.S. (2010). Veterinary pharmaceuticals and antibiotic resistance of Escherichia coli isolates in poultry litter from commercial farms and controlled feeding trials. Poultry Science, 89: 180-188

Gonzalez Ronquillo, M. and Angeles Hernandez, J.C. (2017). Antibiotic and synthetic growth promoters in animal diets: review of impact and analytical methods. Food Control, 72: 255-267.

Gylstorff, I. (1983). Blut, Blutbildung und Blutkreislauf. In: Mehner, A. W. Hartfeiel ( $\mathrm{E} \mathrm{d} \mathrm{s.).} \mathrm{H} \mathrm{a} \mathrm{n} \mathrm{d} \mathrm{b} \mathrm{u} \mathrm{c} \mathrm{h} \mathrm{d} \mathrm{e} \mathrm{r}$ Geflugelphysiologie, Veb Gustav Fisher Verlag, Jena. Pp. 280- 393.

Harr, K.E. (2002). Clinical chemistry of companion avian species: a review. Veterinary clinical pathology, 31 (13): 140 151.

Hernandez, A., Kholif, A.E., Lugo-Coyote, R., M.M.Y. Elghandour, M.M.Y. and Cipriano, M. (2017). The effect of garlic oil, xylanase enzyme and yeast on biomethane and carbon dioxide production from 60-day old Holstein dairy calves fed a high concentrate diet. Journal Cleaner Production, 142: 2384-2392.

Jain, N.C. (1986). Schalms Veterinary Haematology. $4^{\text {th }}$ edition, Philadelphia, USA: Lea and Febiger Publishers. 210 222

Khamisabadi, H, Pourhesabi, G, Chaharaein, B, Naseri, H.R. (2015) Comparison of the effects of licorice extract (Glycyrrbiza glabra) and lincomycine on abdominal fat biochemical blood parameter and immunity of broiler chickens. Animal Science Journal, 105:229-44.

Lamb, G.N. (1991). Manual of Veterinary Laboratory Techniques. CIBA-GEIGY, Kenya. 98-99.

Khalaji, S., Zaghari, M., Hatami, K., HedariDastjerdi, S., Lotfi, L. and Nazarian, H. (2011). Black cumin seeds, Artemisia leaves (Artemisia sieberi), and Camellia L. plant extract as phytogenic products in broiler diets and their effects on performance, blood constituents, immunity, and cecal microbial population. Poultry science, 90(11): 2500-2510.

Medugu, C.I., Kwari, I.D., Igwebuike, J., Nkama,, I., Mohammed, I.D. and Hamaker, B. (2010).Carcass and blood components of broiler chickens fed sorghum or millet as replacement for maize. Agriculture and Biology Journal of North America, 1(3):326329

Kahn, C.M. (2005). The Merck veterinary manual. $9^{\text {th }}$ ed./Whitehouse Station, N.J.; [Great Britain]: Merck \& Co.

Mirtuka, B. M. and Rawnsley, H.M. (1977). Clinical, Biochemical and Haematological Reference Values in Normal Experimental Animals. Masson Publication Company. New York, Pp: 102-117.

Nanbol, D.L., Boniface, N.D., Helen, D.N., Charity, A.A., Deborah, M.A., Peterside, R.K. and Mary, M. (2016). Establishment of reference values for some biochemical and haematological parameters for broilers and layers in plateau state Nigeria. Vom Journal of Veterinary Science, 11: 30-35

Nemi, C.J. (1993). Essentials of veterinary haematology. Publisher: Lea and Febiger Philadelphia. Pp. 278- 290.

Nseabasi, N., Etim, M. E. Williams, U.A. and Edem, A.O. (2014). Haematological parameters and factors affecting their values. Agricultural Science. 2(1):37-47.

Nwaoguikpe, R.N. (2010). The effect of extract of bitter leaf (Vernonia amygdalina) on blood glucose levels of diabetic rats. International Journal of Biological and Chemical Sciences, 4(3).

Ochei, J. and Kolhatkar A. (2008). Medical Laboratory Science, Theory and Practices, Tata McGraw-Hill, Page 311-347.

Oladele, S.B. and Ayo, J.O. (1999). Comparative studies on haematocrit, haemoglobin and total protein values of apparently healthy and clinically sick indigenous chickens in Zaria. Bulletin of Animal Health and Production in Africa, 47 (4): 163-165.

Olaleye, M. T. (2007). Cytotoxicity and antibacterial activity of methanolic extract of Hibiscus sabdariffa. Journal of Medicinal 
Plants Research, 1 (1): 9-13.

Ross, J. G., Christie, G., Halliday, W.G. and Jones, R. M. (1978). Hematological and blood chemistry comparison values for clinical pathology in poultry. The Veterinary Record, 102 (2): 29-31.

SAS (Statistical Analysis System) (2008) SAS for Window, Release 9.1. SAS Institute, Inc., Cary.

Soetan, K. O. Akinrinde, A.S. and Ajibade, T.O. (2013). Preliminary studies on the haematological parameters of cockerels fed raw and processed guinea corn (Sorghum bicolor). Pp. 49-52. Proceedings of $38^{\text {th }}$ Annual Conference of Nigerian Society for Animal Production.

Sebastian, T. Cristina, C., Alexandra, A. and Laurentiu, O. (2012). The relevance of mean blood samples in haematological investigations of broiler chickens. Bulletin
UASMV, Veterinary Medicine, 69 (12):1843-5262.

Wang, C.T., Wang, J.M. and Lin, W.L. (2000). Protective effect of Hibiscus anthocyanins against tert-butyl hydroperoxidase indused hepatic toxicity in rats. Food Chemical Toxicology, 51: 411416.

Wong, P., Yusof, S., Ghazali, H.M. and Che Man, Y.B. (2002). Physico-chemical characteristics of roselle Hibiscus sabdariffa L.). Nutrition and Food Science, 32(2): $68-73$.

Yakhkeshi, S., Rahimi, S., Gharib naseri, K. (2011). The effects of comparison of herbal extracts, antibiotic, probiotic and organic acid on serum lipids, immune response, GIT microbial population, intestinal morphology and performance of broilers. Journal of Medicinal Plants, 10:80-95. 